\title{
Application of Humanism Teaching Theory and Humanistic Approach to Education in Course- books
}

\author{
Yaghoob Javadi \\ Department of Language Teaching and Translation, Varamin-Pishva Branch, Islamic Azad University, Varamine, Iran \\ Mozhdeh Tahmasbi \\ Department of Language Teaching and Translation, Varamin-Pishva Branch, Islamic Azad University, Varamine, Iran
}

\begin{abstract}
The present study aims to use humanism teaching theory and humanistic approach to education with reference to teaching and learning English as a second language in the course-book. The findings of this study revealed that teachers and materials developers use humanism teaching theory and humanistic approach to promote the materials to fit into the needs and preferences of the learners and to facilitate the learning process. The ultimate purpose of the current study is the utilization of humanism teaching theory and humanistic approach to education that was started and is intended for the benefit of humanizing mankind, and to achieve self-actualization learner to learn optimally and also shows that humanizing language learning materials helps language materials developers and teachers to design activities that are associated with learners' lives and experiences and attempt to engage the learners effectively through excitement, emotion, or even fun. However, the need for humanizing language course-books derives from the fact that most of the global course-books accommodate artificial and unnatural activities that are not designed for particular learning program. Hence, through humanizing the course-books, language teachers personalize the learning materials to make them better teaching resources and also individualize them for a particular group of learners. Finally, this text elaborate the application of humanism teaching theory and humanistic approach in education to improve course-books to prepare the learners for more communicative goals to facilitate both language acquisition and personal development.
\end{abstract}

Index Terms-Humanism Teaching Theory, humanistic approach, education, course-book

\section{INTRODUCTION}

According to Prabhavathy and Mahalakshmi (2016), educating and learning process has four viewpoints: 'Educator', 'student, 'Learning procedure's and 'Learning circumstance'. Although the four viewpoints above are a typical instructing and learning circumstance, there are critical contrasts in educating and learning levels Language teaching is more effectual when teachers give a positive personal-image arranging effective situated assignments just as making a supportive Setting.

Mishra (2000, as cited in Shirkhani and Ardeshir, 2013) emphasizes that the focus of humanism is far from education and learning; that the purpose of education is simplify learning, and to facilitate only through the interpersonal correlation with the learner who needs the teacher to, get rid of the emotion of excellence and awareness. Various human language showing techniques which depend on humanism have stressed the job of proper connections between the educator and students as a deciding element in language learning.

As Prabhavathy and Mahalakshmi (2016) stated, nowadays, many linguists who are associated with theoretical or applied research purposes to classify teaching approaches into dual main branches such as the humanist procedures appertaining to the appealing training about an individual, as well as text-based behavioral procedures, that attempt to integrate of what had been acquired during current ages in relation to the demand to effective student involvement, with respect to proper language information as well as relating to transmission such as a human being action. It was greatly emphasized on individual education means a humanistic approach to English language learning that leads to a larger concentrate on the learner.

Based on Arifi (2017), the final aim of humanistic instructing is to make a dependable cultured society which adopts various cultures, in which it is very helpful in knowing one or more foreign languages. The use of the humanistic approach begins with the thoughts that create an educational experience. A humanistic perspective supports the view that educational value is reduced if it does not take in to account the process of learning and the conditions in which learning occurs. In today's society, the focus has been shifting from achieving academic purpose to self-actualization. The formation of acceptable social attitudes and developing empathy is important if one of the goals of education is to enable students to become community leaders. 
Frias (2019) stated that the humanistic approach stresses the learner individual autonomy their preferences, inspiration, self-determination and individual purposes (Woolfolk, 2008). In order for this technique to advance, it is important that a reliable learning environment is supplied to the learners, based on empathy warmth and acceptance of different viewpoints by the teacher. In this approach, the teacher behaves as a facilitator while the student is in govern of their education (Bentham, 2002). Learning either individually or by collaboration with other learners this theory empowers face-to-face cooperation, either in one-on-one cooperation, or in minor clusters and keeps the learner amenable for the process of learning. This learning approach lets the learners achieve academic, personal and life experiences through sympathetic and watching the world in a holistic way.

Tomlinson (2003a) asserts that course-books should increase learners', enthusiasms, excitement and promote them to make significant relationships in their minds. This, actually, increase the importance of revising the course-book to be more humanistic. Humanizing the course-book include not only addition activities that help to create language teaching operation an additional emotional feel but also find behavior to help the students to link whatever is inside the book with whichever they have within mind (Tomlinson, 1995, 1998, as cited in Rahmanpanah \& Mohseni, 2017).

\section{THE CONCEPT OF HuMANIZING}

The word 'humanize' is inferred away from both the term 'humane' plus the name 'human'. The origin of the name 'human' directly denotes association to or respecting humans (man, woman, child) specifically in contrast to both animals plus lifeless things (Nwafor \& Nwogu, 2014). On the contrary, the term 'humane' indicates treating persons or animals within a manner which is not inhuman and imposes similar suffering and afflicted on them. So that humanizing a condition agent treating as conditions it's like a human being. Not as though it is something or something that has no feelings or thoughts. That is to say, humanization in this setting indicates to attribution of human traits to whatever deserves it .So, it removes the sense of being human, that is the colored sense of kindness ,compassion, empathy and attention of others.

\section{EMPHASES OF HUMANISM}

Stevick (1990) states that the word 'humanism' has been utilized in various understandings in the area of foreign language teaching. The various implications have five overlapping accentuations. The first accentuation is sentiments. Humanism dismisses whatever makes individuals feel terrible or whatever crushes appreciating style. Besides, manages social relations. Humanism energizes fellowship and collaboration and rejects whatever may diminish them. The third accentuation is duty. Humanism acknowledges the requirement for open examination, analysis, and remedy, and opposes whoever or whatever prevents the significance from securing such issues. Fourthly, it is intellect. Humanism dismisses whatever meddles with the free utilization of the psyche, and is suspicious about anything that can't be tried mentally. The fifth and last accentuation is self-realization. Humanism accepts that the quest for understanding one's uniqueness prompts freedom. These accentuations incorporate both the improvement of specific characteristics and commitment for accomplishing human potential in language learning (Kemp, 1994). Humanistic standards, when all is said in done, and its accentuations, specifically, make exceptionally significant commitments to unknown dialect educating and learning Shirkhani and Ardeshi (2013).

\section{HumANism TEACHING THEORY}

Prabhavathy and Mahalakshmi (2012) asserted that humanistic hypotheses of learning appears to high esteem centered and henceforth increasingly like remedies (about what should occur) as opposed to depictions of what happens). It qualities the "common want" of everybody to learn. In this way, the instructor requires a lot of power and turns into a facilitator.

\section{The Application of Humanism Teaching Theory}

According to Jingna (2012), one of the important goals of education is self-actualization that followed by all of the humanism educators plus Rogers. Rogers points out that, the only cause is to appease the self-actualization needs the reason is that what is the reason for people to learn, "Self-realization" is talent demand of people moreover this is the very essential internal progress, even the force advance the community. The goal of teaching is to encourage "selfdom" to be recognized. So "self-realization" turns the fundamental teaching purpose. The teaching perfect is to promote "selfactualized." He stresses which inside the world in which we live, the purpose of learning is to promote people with a free and consistent mindset who know the way of learning and how to proceed learning. To consider this hypothesis within real education purpose we don't have to accept the learners as "consenter" who are inactive adverse, impulsive and they do not concern to their feeling. We cannot solely define clear awareness or the purpose of knowledge and nor we can control the purpose or achievement of the goal. When we focus on teaching aim, we need to emphasize the combination of knowledge and ability.

\section{HUMANISTIC APPROACH}


Based on Prabhavathy and Mahalakshmi (2016), the expression 'humanistic' characterize learning approaches that take the fundamental responsibility of the 'whole person' in the process of learning. Effectual education and learning involve the whole person entailing the intellect, the body and the soul. The student is the main individual in the learning process. A humanistic approach is nearly related and have formed numerous theoretical educators' to provoke enthusiasm in this domain to do explore in that concept link to humanistic approach expressing that the learners' first to be address as a human being, then as a learner. Language learning process which includes the whole person which it takes into accounts both the emotion and spiritual demand of human being too.

By the same token, the consequence of the humanistic approach to teaching foreign languages is seen to recognizing the value and role of affection in communication and the attachment of emotions in process of learning, featuring the significance that every learner clarifies the importance and capacity of everybody to have various objectives (Arift, 2017).

\section{A. The Outcome of the Humanistic Approach}

Considering a deteriorating education system appear proper for movement during a humanistic approximation toward teaching. Subsequent the humanistic approach, to education, individual can be strongly guaranteed that learners and teachers are lost in the current education such as honest and ethical values, and patience will be revived between students. This is a powerful community's foundation. It helps us get better education while also allowing us to tackle more social issues like inequality, entrance to property training and so one. The humanistic teaching and learning approach helps us in achieving self-realization which at the heart of education It Philosophers like Rogers also helps it well (Nath et al, 2017).

\section{B. Humanistic Methodologies and Language Teaching Methods Based on 'Humanistic' Theory}

According to Prabhavathy and Mahalakshmi (2012), the four methods which are commonly investigated to consider the philosophy of the humanistic approach Language teaching methods such as Silent Way, Suggestopedia, and Community Language Learning are rooted in humanism principles.

\section{HUMANISTIC EDUCATION}

According to Firdaus and Mariyat (2017), Education has a significant and strategic role to guarantee the progress of cognitive intelligence, psychomotor and affective. Education goals to improve human ability to create a good personality.

\section{HUMANIZING WITHOUT THE COURSE-BOOK}

As Tomlinson (2003), points out, majority of the non-humanized course books diminish the learners from an intellectual learner with perspectives, opinions, and affection to an unemotional language learner, concentrating on lowlevel linguistic decoding. One of the human ways in the textbook is that the teacher replaces some of it with more human material that includes learners to obtain and reflect on the experience, or the teacher is a step by step alternative to this textbook (Tomlinson ,2013).

\section{HUMANIZING WITH THE COURSE-BOOK}

Tomlinson (2010), maintains that most instructors are required to apply a textbook during entire their lesson. In such situations, they can humanize it along diminishing the book,s inhumane component and developing and appending it to those parts that make learners think, feel and do it for learning. An example of such approach is as follows: The first is asking the whole class to change the text of text-lessons from the teacher's speech through instructions and then training them the text of the book and asking them in groups to distinguish many differences as they can apply between two similar texts at a limited time. And also the instructor can organize a competition in which groups put it at the bturn in order to express differences without referring to returning to the text. The other method can be stimulating the groups to improve a widespread version of the text in a local context and the last process is providing students with some course Book activities for homework (Tomlinson ,2013).

\section{DeVEloping HuMANistic COURSE-BOOKS}

Of course, an ideal scenario for many hard-pressure teachers is able to use a course-book that is currently human. Can it be possible to created human-readable textbooks that simultaneously meet the conventional perceptions about journalists also the needs of established schools, curriculum and managers? This is. However this is not comfortable; and no course-book can be fully humanistic for total its consumers, as it cannot be directly related to the user's life (Tomlinson, 2013). There are a number of ways to create textbooks that are more humane.

\section{A. Writing in Large and Varied Teams}

Tomlinson (2013), maintains that writing course-book a specific set of course-book can be a long one, hard and difficult process. Often the author (s) begins with excitement and energetic concept. but they begin to miss your imaginative energy subsequently construction approximately unavoidable accommodation with the conventional and 
understandable editor, and after fading countless components of the same form. Writing a course-book in large and diverse teams is one way to stimulate and maintain creative inner energy. The team may include new and experienced teachers, new and experienced materials writers, poets, an artists. Musicians, supervisors, and a cartoonist, gathering all of their resources and provoking each other.

\section{B. Using a Text-driven Approach}

In Tomlinson's experience and commentary as an author and promoter about textbooks using a Text -based Approach can be a greatly effectual fashion to guarantee in order to a course-book is humanitarian and to ensure humanitarian bookstore too. If the initial focus is on a potentially attractive text, it is likely that mind authors keep the students in mind, rather than focusing on an element or language proficiency. And its considerable simpler to expand the learning actions to correspond the content it is to discover the attractive text to fit the teaching point

(Tomlinson, 2013).

\section{Using Multi-dimensional Approach}

A multi-dimensional approach aimed at helping students expand their capability to generate and operation by employing their intellectual resources in a manner corresponding to that used through their communication in LI. Doing this not only helps students maximize their brain's potential for communication on L2, but also fits the text and maximizes their brain-power for learning (Tomlinson 2000a). A multidimensional approach is based on the principle that the use of effects, the mental, the image and the inner speech, and what we do throughout the use of effective language, and what we do during effective and durable learning (Tomlinson ,2013).

\section{Using Literature}

Tomlinson (2013) ,maintains that using Literature in Tomlinson's Experience one of the best ways to achieve the goals of developing Humanistic Course-books is to use literature as a means to stimulate multidimensional mental activity during language learning(Tomlinson, 2001). This is the only act if learners are encouraged to experience the literature, rather than studying it. He has found that the best way to do this is to create a linguistic library that is linguistically simple but cognitively and emotionally complex, and then they are used as the basis of human activity that encourages personal appointment and responds (Tomlinson, 1994a).

\section{E. Varying the Unit Focus}

One of the causes why several course-books are designed superficial and boring, is that the majority of them work in each unit to cover four skills added to grammar, vocabulary and pronunciation spelling. This certainly causes bits- and pieces approach, which often provides only very short, trivial, and mutual collision with the learned language. If most units have only one central focus, there is a better chance of dealing with more constant and meaningful engagement with language in use and, likewise, creating a human learning book. In this way, more emphasis is placed on the focus of attention between individuals and less on non-related bits of language. And language work will be linked to what the students have already experienced and feel (Tomlinson , 2013).

\section{F. Talking to the Learner}

The voice of the majority of the text-books is semi-official and distant, and matches with the stereotype teacher speaks of knowledge transfer to their learners. Very few writers show their personal interests, beliefs and experiences, and spend most of their time talking to learners about what they should learn, do, and what to say or interrogate. This is a very unfair and inhumane relationship (but it's not too small to encourage or engage in the learner (Tomlinson ,2013).

\section{G. Connecting to the Learners, Views and Opinions}

Connecting Students' Views is the easiest way to create a human course-book that ensures that in most learner activities about their views, attitudes, feelings and beliefs, which they are thinking of communication and their own connections and feel that they are the same as interactions with course-book writers and text writers that this book contains. No many course-books do this perfectly (Tomlinson, 2013).

\section{H. Providing Text-free Generalizable Activities}

Humanistic and more productive can be an approach that selects generalizable and public activities in a course-book with direction and motivation to help learners use their texts for use with their own activities (Tomlinson, 2013).

\section{Including Awareness Activities}

Tomlinson (2010) asserted that language awareness activities ( Bolitho \& Tomlinson,1995), and pragmatic awareness activities (Tomlinson, 1994b) and cultural awareness activities ( Tomlinson,1995) in which students work ultimately, and do things for themselves, It can facilitate not only the promotion of language and mental development, but it can also noticeably increase self-esteem and independence.(Tomlinson ,2013).

\section{J. Providing Alternatives}


Providing a path selection of texts and tasks is a relatively easy way to text-book and thus make them more individualized and humanistic (Tomlinson, 2013).

\section{K. Localizing Course-books}

Course-books have been localized to connect a course-book to the real world that the learner lives. Unfortunately, textbooks do not produce global textbooks, and the recent trend in the production of common textbooks has become the source of most English language learners in the world (Tomlinson, 2013).

\section{REVIEW OF THE RELATED LITERATURE}

\section{A. Humanism}

Socrates, Plato, Aristotle, Locke, Rousseaue, Kant, and Pestalozzi are a few of the huge humanists of the world history. Humanism has been created as a way to deal with training and learning standards since the 1960s as subjective and conduct and the impression of a person as an article in logical research. It starts with the confidence in the inherent great of man, and is as per the Sigmund Freud and Biological methodologies that guarantee that human conduct and cognizance are resolved through past encounters and occasions. The most significant human authors who framed this hypothesis were Carl Rogers and Abraham Maslow, whose works were to a great extent dependent on character recognition.

In sum, ( Mishra (2000), as cited in Shirkhani and Ardeshir, 2013) emphasizes that the focus of humanism is far from education and learning the purpose of education is to facilitate learning and facilitate only through interpersonal communication with a learner who needs a teacher, Get rid of the emotions of excellence and knowing everything.

\section{B. Humanism Teaching Theory}

According to Jingna (2012), the hypothesis of education is grounded in the theory of being personality. They considered which humanism was a congenital actuality, yet not community realism. Being nature is entrenched in nature in addition to here is the methods about human being. According to, Rahman 2013, language include various techniques : these methods are Suggstopaedia, Silent Way plus Community Language learning (CLL), along with Total Physical Response (TPR). These are human in the feel which they embrace humanistic attitudes and come out of the same mental processes and philosophical scholarship. Given the factors influencing humanist theory, Nunan (1991 as cited in Sinclair, 2006, p. 239,) states if they are followed correctly they will surely lead to successful learning, and the lack of it will in practice bring the last theory ill not fail.

\section{Humanistic Approach}

Stevick (1980, as cited in Prabhavathy \& Mahalakshmi 2016) categorized the majority of important features of humanism that include feelings, personal, emotional and creative admiration while social relationship include the side of humanism which promote intimacy and partnership and so intellect relate knowledge, reason and understanding and awareness with self-actualization which is the adventure for complete identification of one's own deepest true qualities.

\section{Humanistic Education}

According to shih (2018), a few years ago, humanistic education was expanded as a response to exposure to harmful or unhealthy environments in several classrooms (Patterson, 1987 concern. reality. As an individual understands the extent of dehumanization, maybe it is to ask whether humanization is a reasonable possibility. Throughout history, under certain fundamental conditions, both humanization and dehumanization have opportunities for an unfinished individual who is aware of his incompletion (Freire (2000), Cited in shih, 2018).

\section{E. Humanistic Curriculum}

Broom (2014) stated that many parts of the humanistic educational program were conspicuously shown at the tallness of their inventive self-articulation in workmanship training during the 1960s and 1970s (Zimmerman, 2010), and from the thoughts of Viktor Lowenfeld (1964) that underlined the significance was motivated .reinforce inventiveness and singularity in understudy fine art. In spite of the fact that singularity is a point of noticeable quality in humanistic educational plans, pleasing learning and aggregate work are additionally featured as approaches to sustain social and passionate needs and to show understudies the benefit of cooperating while at the same time getting struggle of conviction, foundation, and encounters (Huitt, 2009; McNeil, 2009). With this accentuation on peer participation and on comprising multidimensional study halls which produce understudies with significant levels of inclination in investigating pull in, the humanistic educational program imparts much in like manner to constructivist learning hypotheses (Shunk, 2004) that guess that individuals immediately build information through their collaboration with others and through straight experience (DeVries, Edmiaston, Zan, and Hildebrandt, 2002).

\section{F. Humanizing with the Course-book}

According to Tomlinson (2008), Brian Tomlinson is a visiting professor at Leeds Metropolitan University, UK, and an independent consultant based in Langkawi, Malaysia and a Chairman President of MATSDA (Association for Material Development). Tomlinson has worked in Indonesia, Japan, Nigeria, Oman, Singapore, Vanuatu and Zambia 
and has presented more than sixty conference presentations in these countries. Offering in these countries his numerous publications include English Discovery, Extension of Language Teaching Materials, Provision of Language Teaching Materials and English Language Teaching. In Tomlinson (2003a), he explored the humanization of textbooks and provided examples of many of the practices he has used to achieve this goal over the past forty-three years.. Hitomi Masuhara and Tomlinson joined the Sultan Qaboos University (SQU) Language Center as a curriculum specialist in September 2007. Their important function was to carry on their act like a consultant in January 2007 to direct teachers in the preparation of specific materials to replace the current commercial textbooks. They also helped three teachers complete a new writing course at Level 2 and are now working on a Level 3 reading and writing course with six teachers. A text-based approach accompanies the content in these new courses (Tomlinson 2003b), and informs them through humanistic principles such as localization (Tomlinson 2006), personalization, flexibility, multidimensional representation, cognitive stimuli, and emotional involvement. Be. They now have a positive impact on students' motivation and development.

The textbooks Tomlinson was given for use in various classes were Philips (2003a, 2003b, 2003c). There are members of a language proficiency program planned to make ready learners for admission to English language research and the other EAP textbooks are no better or worse that he has encountered. Like most of them, in his opinion, they lack appealing content and challenging actions, and they might be significant improved by listening to Mol and Bin's (2008) terms, which state in one chapter of the EAP, "The emotional dimension of learning demands should be improved. Design activities and materials. Suggestions for teachers should be given to motivate students and maximize their cognitive and emotional involvement in the content. "When Tomlinson began using textbooks, he quickly realized that although the curriculum Language and skills may be approximated with what students need. Texts and activities are not unlikely to stimulate or engage students.

\section{DiscusSION}

The present research study focuses on the application of humanism teaching theory and humanistic approach to education in course-books. This paper shows that teachers and materials developers in promoting the materials to fit into the affective states, needs, and preferences of the learners and to apply course books that related to the learners' needs and wants and to facilitates the learning process use humanism teaching theory and humanistic approach. However, the need for humanizing language course-books derives from the fact that most of the global course-books contain artificial and unnatural activities that are not designed for particular learning program. The major problem with global course-books is that they lack excitement and disturbance as they are filled with dull and meaningless activities. Hence, through humanizing the course-books, language teachers personalize the learning materials to make them better teaching resources and also individualize them for a particular group of learners. This text will elaborate the application of humanism teaching theory and humanistic approach in education to improve text-books to prepare the students for more communicative purposes and shows humanistic approach to language learning can facilitate both language acquisition and personal development. Several of these course-books focused on quantitative and theoretical aspects of language learning and neglected to examine the multidimensional cognitive capacity of the human being. The coursebook and its contents should not be in contrast with moral and cultural and political values in our society. The topics of textbook should be interesting for learners. Reading text should not be long and difficult for students. Textbook content should be designed in such a way which prepares students for more communicative purposes. Tomlinson (2008) said that when he started to use the textbooks he quickly realized that although language and skills curricula may be exactly what student's need, texts and activities can be stimulating or engaging. Students are unlikely to do so. He specifically identified the following specific problems: Since "low-level" learners must focus primarily on mastering low-level skills and hence merely extremely rarely do eighteen-year- -olds learn the use of such a high level of focus. Skills such as inference, interpretation, problem solving and creation. Moreover, texts are typically "dry" and have little potential for cognitive and emotional interaction. In addition, many texts and activities have little to do with eighteen-year-old university students in Oman (for example, Romeo and Juliet and Night Guy Fawks in the UK). In addition, many activities are meaningless, mechanical, and unlikely to stimulate or assist students in profound language processing, and many activities test what students can do instead Providing learning opportunities (e.g. of minimal pair exercises lacking previous listening; grammar tasks that ask questions that cannot be replied with any accessible evidence) and most tasks do not involve any cognitive challenges. Finally, every part follows precisely the same format, repeating the same styles of exercises and repeating other type of, exercises have little potential value (e.g. paragraph matching with topic sentences). The findings of the current study are in line with the number of studies (e.g. Hutchinson \& Torres, 1994; Sheldon, 1988; Goleman, 1995, 2006; Tomlin son, 1990, 1994).

Textbooks are at the heart of English teaching settings (Hutchinson \& Torres, 1994; Sheldon, 1988). In fact, the view of flow attack directed attention, full involvement, high attract, and goal-directedness. Similar to the current situation, the learner engaged in absorbing what he or she knows seems to integrate his or her consciousness with his/her actions (Goleman, 1995, 2006).

In addition, the findings are consistent with another number of studies (e.g. Berman, 1999; Arnold, 1999; Craik \& Lockhart, 1972; Maley, 2003, 2008; Masuhara, 2006; Tomlinson, 1998a, 1998b 2003a, 2003b, 2008, 2010, 2013; Arnold, 1999).Through the support of whole-brain learning that learners can increase their learning operation by 
attracting their feeling, affection, and fancy. Moreover, Berman (1999), believes that 'affect' is a very important factor in learning. Most publications emphasize the demand to expand emotionally appealing materials which needed for all style learning selection (Craik \& Lockhart, 1972; Arnold, 1999; Maley, 2003, 2008; Masuhara, 2006; Tomlinson, 2003, 2008). So to have a course-book that promotes the process of learning, it should be associated with the learners' requirements and desires however, it is hardly respected that (Tomlinson 1998). Moreover (Tomlinson, 1998b, 2003b), maintained that the main problem with global course books are planned to simplify localization and personalization (course-books is that they absence warmth and agitation as they are full with boring and senseless activities. in addition, non-humanistic course-books do not tries to involve the learners emotionally through warmth, affection, or even fun (Arnold, 1999; Tomlinson, 2003a) .Moreover, many researchers condemn global course books on basis that published materials do not include the kinds of actions and texts a teacher is searching a particular group of partners in a particular setting(; Tomlinson, 2003b) . Moreover, Tomlinson (2010), argued that the majority of the instructional materials goal to convince the wants of the only idealized cluster of target learners. Similarly, Tomlinson (2010), believes that the humanistic course-book will affect imaging, inner sound, and student movement activities. The humanitarian bookstore can be done by reducing the inhumane elements of the book and expanding the parts of the textbook that invites learners to think, feel and perform learning. Moreover, as Neal and Miller (2006), point out, learner involvement plays a crucial role in the learning process. Similarly, Tomlinson (2010), believes that humanistic course-books involve learners' effect by supplying imaging, inner sound, and physical activities. Therefore, humanizing materials promote language learners to relate course-book and their own lives (Tomlinson, 2001).In sum, what Tomlinson (2013), means by a humanitarian course-book is one that admires its users like a human being and makes it easier for them to use their learning skills through purposeful experience .He hopes it as well becomes evident which 'humanizing the coursebooks' means adding activities that helps the language learning operation to be extra effective skill and discovery solutions that helps the students to link whatever inside the book with whatever inside their minds.

\section{CONCLUSION}

The use of the humanistic approach begins with the thoughts that create an educational experience in today's society, the focus has been shifting from achieving academic goals to self-realization. The final aim of humanistic teaching is to create society responsible for civil society that has adopted a variety of cultures that are heavily contributing to one or more foreign languages. The number of approaches has affected and informed teaching and learning. Every technique operates in its own way and attempts to strengthen it. All these new perspectives have an educational effect on the current education and teaching. Humanistic approaches to language learning can promote both language acquisition and personal development. Tomlinson (2003), points out that most inhumane books reduce the learner's ability to learn from a smart learner with views, attitudes, and feelings to an un-manifested language learner, focusing on linguistic decoding. Unfortunately, many language learners learn from the books and most of the course books are not human. However, course books are less flexible and there is the possibility of creating course books that are both humane and profitable. In this way, it is for teachers to adapt the textbooks to become more humanized and personalized. Students know better what they want and need to know. It means that the learners will learn more easily and quickly when analyzing the skills that matters to them and for that reason as well as the skills to guide their behavior towards those who are needed and wanted. The present research study aims to use humanism teaching theory and humanistic approach to education with reference to teaching and learning English as a second language in course-book. The findings of this study revealed that teachers and material developers have used humanism teaching theory and humanistic approach to promote materials in accordance with the learner's effective conditions, needs and preferences and to apply course books that related to the learners' demands and wants and desires and to facilitate the learning process. The ultimate purpose of the current study is the utilization of humanism teaching theory and humanist approach to teaching and the teaching process which has been initiated and is planned for purpose of humanizing society, and for achievement selfactualization learner to understand perfectly and also shows that a humanism theory and humanistic approach to education improve on the learner as an individual, taking their interests and aims as the basis to organize or to produce and facilitate their learning experiences. Furthermore, Humanizing language learning materials helps language material developers and teachers to design activities that are associated to learners' lives and experiences and attempt to engage the learners effectively through excitement, emotion, or even fun. .However, the need for humanizing language coursebooks derives from the fact that most of the global course-books accommodate artificial and unnatural activities that are not designed for particular learning program. Hence, through humanizing the course-books, language teachers personalize the learning materials to make them better teaching resources and also individualize them for a particular group of learners. Finally, this text elaborates the application of humanism teaching theory and humanistic approach, in education to improve text-books to prepare the learners for more communicative goals to facilitate both language acquisition and personal development. Finally, a humanistic language teaching methods may promote language learning as well as personal development. Sadly, learning from course-books is not humanistic for many language learners as well as most course-books are not humanistic. Nonetheless .making more humanistic course-books is not that unmanageable, and course-books that are both humanitarian and profitable can be improved. 


\section{REFERENCES}

[1] Arifi, Q. (2017). Humanistic Approach in Teaching Foreign Language (from the Teacher Perspective). European Scientific Journal. Prishtina 13(35), 194-20

[2] Arnold, J. (ed.) (1999). Affect in language learn-ing. Cambridge: Cambridge University Press.

[3] Bentham,S. (2002).Psychology and Education East Sussex: Routledge. https://www.taylorfrancis.com/books/9781134587483.

[4] Berman, M. (1999). The teacher and the wound-ed healer. IATEFL Issues, 152, 2-5.

[5] Broome. J.L (2014). Commentary - The Case for Humanistic Curriculum: A Discussion of Curriculum Theory Applied to Art Education. Journal of Art for Life 5(1), 3-4.

[6] Mol, H. and Bin, T. B. (2008). 'EAP materials in Australia and New Zealand. In B. Tomlinson (ed.) English Language Teaching Materials. London: Continuum.

[7] Craik, F. I. M., \& Lockhart, R. S. (1972). Levels of processing: A framework for memory research. Journal of verbal learning and verbal behavior 11(6), 671-684.

[8] DeVries, R., Edmiaston, R., Zan, B., \& Hildebrandt, C. (2002). What is constructivist education? Education 63(5), 84-92.

[9] Firdaus, F. A., \& Mariyat, A. (2017). Humanistic Approach In Education According To Paulo Freire. At-Ta'dib 12(2), 25-48.

[10] Freire, P. (2000). Pedagogy of the oppressed. New York, NY: The Continuum. Halliday, M. A. K., McIntosh, A. and Stevens, P. The Users and Uses of Language. http://www.meshguides.org.

[11] Frias, J. (2019). Improving learning experiences by using Humanism and Constructivism teaching approaches in the classroom. Philosophy of Education. T\&L cert. John Wiley and Sons 1(1), 1-5.

[12] Goleman, D. (1995). Emotional Intelligence. New York: Bantam Books.

[13] Goleman, D. (2006). Emotional Intelligence. New York: Bantam Books.

[14] Huitt, W. (2009). Humanism and open education. Educational Psychology Interactive. Retrieved from http://www.edpsycinteractive.org/topics/affect/humed.html.

[15] Hutchinson, T. \& Torres, E. (1994). The textbook as agent of change. ELT Journal, 48(4), 315-328. In J. Webster, ed. Language and Society. London and New York: Continuum, 10 (2007).

[16] Jinga, D. (2012). Application of humanism theory in the teaching approach. Higher Education of Social Science 3(1), 32-36.

[17] Kemp, J. B. (1994). Arousing the sixth emphasis within humanism in English language teaching. ELT Journal 48(3), $243-252$.

[18] Lowenfeld, V. (1964). Viktor Lowenfeld speaks on art and creativity (W. L. Brittain, Ed.). Reston, VA: NAEA.

[19] Maley, A. (2003). Creative approaches to writing materials. In B. Tomlinson (Ed.) Devel-oping Materials for Language Teaching (pp. 183-198). London: Continuum.

[20] Maley, A. (2008). Extensive reading: Maid in waiting. In B. Tomlinson (ed.), English language learning materials: A critical review, London: Continuum, 133-156.

[21] Masuhara, H. (2006). Themulti-dimensional awareness approach to content teaching. In J. Mukundan (ed.), Focus on ELT Materials (pp.1-11). Petaling Jaya: Longman.

[22] McNeil, J. D. (2009). Contemporary curriculum: In thought and action (7th ed.). Hoboken, NJ: John Wiley and Sons.

[23] Mishra, C. (2000). Humanistic approach to education. Journal of NELTA. 5, (2), pp.26- 29.

[24] Mol, H. and Bin, T. B. (2008). 'EAP materials in Australia and New Zealand. In B. Tomlinson (ed.) English Language Teaching Materials. London: Continuum.

[25] Nath, A. Kumar, R. \& Kumar Behura, A. (2017). Humanistic Approach To Education: A Look in to the Humane Perspective Of Teaching and Learning. Global Journal of Engineering Science and Researches. ISSN: 2348 - 8034. Impact Factor- 4.022.

[26] Neal, L., \& Miller, D. (2006). The use of tech-nology in education. In O'Neil, H. F. and R. Pere, Web-based learning: Theory, research, and practice. UK: Lawrence Erlbaum Associates.

[27] Nunan, David. Language Teaching Methodology. Herts: Prentice Hall, 1991.

[28] Nwafor, H.A and Nwogu, U.J. (2014). Humanising the Classroom: A Pragmatic Approach. European Scientific Journal.vol.10, No.19.

[29] Philips, T. (2003a). Skills in English - Reading Level 1. Reading: Garnet Education.

[30] Philips, T. (2003b). Skills in English - Speaking Level 1. Reading: Garnet Education.

[31] Philips, T. (2003c). Skills in English - Listening Level 1. Reading: Garnet Education.

[32] Prabhavathy. P. and Mahalakshmi S. N. (2012). ELT with specific regard to humanistic Approach. IOSR Journal of Humanities and Social Science, Volume 1, Issue 1, PP 38-39.

[33] Prabhavathy. P. and Mahalakshmi S. N. (2016). The Development of the Humanistic Approach in English Language. Journal of Pune research. Vol 2, issue 3.

[34] Rahman, M. (2013). 'Humanistic Approaches' to Language Teaching: from Theory to Practice. Stamford Journals of English. 4. 10.3329/sje.v4i0. 13491.

[35] Rahmanpanah, R. and Mohseni, A. (2017). Engagement and Motivation in EFL classroom: Humanizing the Coursebook or Autonomy-supportive Teaching Climate. Journal of Language and Translation, Volume 7, Number 1(13), (pp.69-88). River, NJ: Peason.

[36] Schunk, D. H. (2004). Learning theories: An educational perspective (4th Ed.). Upper Saddle

[37] Sheldon, L. (1988). Evaluating ELT textbooks and materials. ELT Journal, 37(3), 1-9.

[38] Shih, Y, H. (2018) .Towards a Pedagogy of Humanizing Child Education in Terms of Teacher-Student Interaction. Journal of Education and Learning; Vol. 7, No. 3.

[39] Shirkhani, N. and Ardeshir, D. (2013). Humanism in the Foreign Language Classroom. I-manager's Journal on English Language Teaching, Vol. 31 No. 4.

[40] Sinclair, Barbara. Humanism. (2006). In: Syllabus Design and Methodology Handouts. MA ELT, University of Nottingham, Malaysia Campus.

[41] Stevick, E. W. (1990). Humanism in language teaching, Oxford: Oxford University Press. 
[42] Stevick, Earl, W. (1980). In Teaching Language: A Way and Ways. Rowley, MA: Newbury House, Xiv+304. 2010. TeacherStudent Interaction. Journal of Education and Learning; Vol. 7, No. 3.

[43] Stern, H. H. Fundamental Concepts of Language Teaching. Applied Linguistics, 5th ed. Oxford: University Press, 1983.16-24.

[44] Tomlinson, B. (1990). Managing change in Indo-nesian high schools. ELT Journal, 44(1), 25-37.

[45] Tomlinson, B. (1994). Materials for TPR. Folio, 1(2), 8-10.

[46] Tomlinson, B. (1994a), Openings. London: Penguin.

[47] Tomlinson, B. (1995), 'Work in progress: textbook projects', Folio, 2 (2), 14-17.

[48] Tomlinson, B. (1995). Work in progress. Folio, 2(2), 26-30.

[49] Tomlinson, B. (1998a). Affect and the course-book. IATEFL Issues 145, $20-21$.

[50] Tomlinson, B. (1998b). And now for something not completely different: An approach to

[51] Tomlinson, B. (1998c). Introduction. In B. Tom-linson (Ed.), Materials development in language teaching (pp. 1-24). Cambridge: Cambridge University Press.

[52] Tomlinson, B. (2000a). 'A multi-dimensional approach', The Language Teacher Online, 24 July.

[53] Tomlinson, B. (2001). 'Connecting the mind: a multi-dimensional approach to teaching language through literature', The English Teacher, 4 (2), 104-15.

[54] Tomlinson, B. (2003a). Humanizing the course-book. In B. Tomlinson (Ed.), Developing materials for language teaching (pp. 162-173). London: Continuum Press.

[55] Tomlinson, B. (2003b). Developing prin-cipled frameworks for materials devel-opment. In B. Tomlinson (Ed.), Devel-oping materials for language teaching (pp. 107-129). London: Continuum Pressa.

[56] Tomlinson, B. (2006). 'Localising the global: Matching materials to the context of learning.' In J. Mukundan (ed.), Readings on ELT Materials II. Petaling Jaya: Pearson Malaysia, 1-16.

[57] Tomlinson, B. (2008). Humanising an EAP Textbook. Humanising Language Teaching. Year 10; Issue 2. Year 10; Issue 2; April 2008, ISSN 1755-9715.

[58] Tomlinson, B. (2010). Principles and procedures of materials development. In N. Harwood (Ed.), Materials in ELT: Theory and Practice. Cambridge: Cambridge University Press.

[59] Tomlinson, B. (2013). "Humanizing the Coursebook." in B. Tomlinson (ed.), Developing Materials for Language Teaching, London: Bloomsbury, pp. 140-152.

[60] Williams, Marion and Robert L. (1997). Burden. Psychology for Language Teachers. Cambridge: Cambridge University Press.

[61] Woolfolk, A. (2008). Educational Psychology (10th Ed.). USA: Person Education Inc. https://www.pearson.com/us/highereducation/product/Woolfolk-Educational-Psychology-Active-Learning-Edition-10th-Edition/9780205542789.html.

[62] Zimmerman, E. (2010). Creativity and art education: A personal journey in four acts. Art Education, 63(5), 84-92.

Yaghoob Javadi is an assistant professor of Applied Linguistics at Department of Language Teaching and Translation Studies at Islamic Azad University, Varamin-Pishva branch, Iran where he teaches post-graduate courses including Second Language Acquisition Studies, Curriculum Planning, Computer Enhanced Language Learning, and Language, Culture and Identity. His current research interests include cultural and cognitive aspects of second language acquisition, identity, CALL, curriculum planning and teacher education.

Mozhdeh Tahmasbi is a Ph. D Candidate of Applied Linguistics at Department of Language Teaching and Translation Studies at Islamic Azad University, Varamin-Pishva branch, Iran. 